\title{
Anxiolytic-Like Effects of Cyclopeptide Fraction Alkaloids of Zizyphi Spinosi Semen: Possible Involvement of $\mathrm{GABA}_{A}$ Receptors
}

\author{
Huishan $\mathrm{HAN}^{\mathrm{a}}$, Yuan $\mathrm{MA}^{\mathrm{b}}$, Jae Soon EuN ${ }^{\mathrm{c}}$, Jin-Tae HoNG ${ }^{\mathrm{a}}$, and Ki-Wan $\mathrm{OH}^{\mathrm{a}^{\star}}$ \\ ${ }^{a}$ College of Pharmacy, Chungbuk National University, Cheongju 361-763 Korea. \\ ${ }^{b}$ Research Institute of Veterinary Medicine, Chungbuk National University, Cheongju, 361-763 Korea. \\ ${ }^{c}$ College of Pharmacy, Woosuk University, Samrye 565-701 Korea
}

(Received August 1, 2008; Revised September 1, 2008; Accepted September 2, 2008)

\begin{abstract}
This experiment was performed to investigate the anxiolytic-like effects of cyclopeptide fraction alkaloids of Zizyphi Spinosi Semen (CFAZ), by using the experimental paradigms of anxiety, and compared with those of a known anxiolytic, diazepam. CFAZ $(8.0 \mathrm{mg} / \mathrm{kg}$, p.o.) increased the percentage of time spent on the open arms and the number of open arms entries in the elevated plus-maze test, increased the number of head dips in the hole-board test, and increased the percentage of center zone ambulatory time in the open-field box. However, CFAZ has no effect on the locomotor activity, while diazepam $(2.0 \mathrm{mg} / \mathrm{kg}$, p.o.) significantly reduced locomotor activity. CFAZ did not influence the grip force in the grip strength meter test, either. From the molecular experiments, CFAZ increased chloride influx in cultured cerebellar granule cells. In addition, $G_{A B A}$ receptors $\gamma$-subunit were over-expressed by CFAZ in cultured cerebellar granule cells. It is concluded that CFAZ may have anxiolytic-like effects, and these effects may be mediated by $G_{A B A}$ receptors.
\end{abstract}

Keywords: Zizyphi Spinosi Semen, Cyclopeptide fraction alkaloids, Anxiolytic-like effects, Elevated plus-maze, Hole-board, Open field, Locomotor, Grip strength, Chloride influx, $G_{A B A}$ subunit

\section{INTRODUCTION}

Anxiety affects one-eighth of the total population worldwide and has become an important area of research interest in psychopharmacology (Eisenberg et al., 1998). Anxiety disorders present in a number of forms, although probably all share a number of common neurological circuits (Beck, 1988). Benzodiazepines have been used for the treatment of several forms of anxiety although these compounds have well-known their side-effects such as sedation, muscle relaxation, amnesia and drug dependence (Gardner et al., 1993). So, many researchers have been evaluated new compounds with less undesirable effects from herbs.

Various traditional herbal medicines have also been suggested to possess anxiolytic activity. Some of them such as St. John's wort and ginseng have been introduced for clinical treatment of anxiety (Park et al., 2005). In addition, it is also reported that the saponin-containing

\footnotetext{
${ }^{*}$ Corresponding author

Tel: +82-2-43-261-2827 Fax: +82-2-43-261-2827

E-mail: kiwan@chungbuk.ac.kr
}

fraction of the leaves of Albizzia lebbeck from India have anxiolytic effects (Une et al., 2001). In addition, it is reported that kava-kava (Piper methysticum Forst) also has the anxiolytic-like effect (Duarte et al., 2007; Rex et al., 2002). Recently, the new study indicated that Saiboku-to, a herbal prescribing medicine showed an anxiolytic-like effect (Yuzurihara et al., 2000). Research also has focused on the development of drugs with fewer side effects such as sleeping, muscle relaxation and drug dependence.

Zizyphi Spinosi Semen (ZSS), the dried seed of Zizyphus jujuba Mill var. spinosa (Rhamnaceae), has been known to contain many pharmacologically active components. It has been used as an analgesic, tranquilizer and anticonvulsant in oriental countries such as Korea and China and has been prescribed for the treatment of insomnia and anxiety in Asia (Peng and Zhu, 2001). This herb medicine is rich in many pharmacological active compounds, such as flavones, alkaloid and triterpenes (Lee et al., 1996; Cheng et al., 2000), which could improve cognitive function for anti-cholinesterase activity, protect NMDA-induced neuronal cell damage (Park et al., 2004), increase sleep time induced by pentobarbital 
(Adzu et al., 2002; Ma et al., 2008), inhibit caffeineinduced excitation and prolong hexobarbital-induced sleep (Chung et al., 2002). The recent study reported that alkaloid fraction and flavonoids of the seeds can produce central inhibitory activity (Park et al., 2004). It has been investigated that the ethanol and methanol extract of ZSS have the anxiolytic-like effect (Peng et al., 2000; Han et al., 2007). It is also been indicated that the aqueous extracts of Sanjoin-Tang has the anxiolytic-like effects in mice (Ahn et al., 2004).

GABA systems are the most ubiquitous mechanisms on anxiolytic effects. GABA is the main inhibitory neurotransmitter in the brain (Kaupmann et al., 1997) and it is known to interact with three receptor types, $G_{A B A}$ $G_{A B A}$ and $G A B A_{C}$. The $G A B A_{A}$ receptors are probably the most complicated which are heteromeric ligand-gated chloride ion channels. Seven isoforms of its subunits $(\alpha$, $\beta, \gamma, \delta, \pi, \varepsilon$ and $\theta$ ) containing 16 subtypes ( $\alpha 1-6, \beta 1-3, \gamma 1-$ $3, \delta, \pi, \varepsilon$ and $\theta$ ) have been discovered (Barnard et al., 1998; Bonnert et al., 1999). And, where they meet, forms a channel through which chloride ions can pass. In normal circumstances, opening of the chloride channel causes the negative chloride ions to flow into the cell, causing hyperpolarization and thus inhibition of cellular activity (Whiting, 1999). GABA $A_{A}$ receptors are important drug targets for a variety of medications used to treat anxiety and insomnia. GABA $A_{A}$ receptors have a rich pharmacology because they have a number of separate binding sites for a variety of drugs that can modulate the activity of GABA (Bateson, 2004). $\mathrm{GABA}_{\mathrm{A}}$ receptors possess different binding sites such as GABA, barbiturate, benzodiazepine and picrotoxin (Brailowsky and Garcia., 1999). The heterogeneity provides the structural basis for differential targeting by receptors subtype-selective drugs to improve the treatment of insomnia, anxiety, epilepsy and alcohol withdrawal (Korpi et al., 2002).

Benzodiazepines bind to $\mathrm{GABA}_{A}$ receptors. Their binding sites differ from that of GABA. The principal effect is a change in $\mathrm{Cl}^{-}$conductance. Both of the affinity and the efficacy of benzodiazepine is determined by $\alpha$ and $\gamma$ subunits of $\mathrm{GABA}_{A}$ receptor. Benzodiazepines are used to treat lots of clinical symptoms such as anxiety, convulsion and muscle tension (Whiting, 1999). The anxiolytic effect of benzodiazepines is due to allosteric modulation of $\mathrm{GAGA}_{A}$ receptors, leading to GABAergic neurotransmission. Positive allosteric modulators increase the frequency of chloride openings without altering the channel conductance or duration of opening. Therefore, they are used as anxiolytic, anticonvulsant, sedative-hypnotic, and muscle relaxant drugs (Hui et al., 2002).
This experiment was performed to investigate the anxiolytic-like effects of CFAZ, one of major alkaloid compounds of ZSS by using the experimental paradigms of anxiety such as elevated plus-maze, hole-board, open field and compared with those of a known anxiolytic, diazepam. In addition, chloride influx in primary cerebellar neuronal cells and $\mathrm{GABA}_{\mathrm{A}}$ receptors subunits expression are measured to understand the possible mechanisms of CFAZ.

\section{MATERIALS AND METHODS}

\section{Animals}

Male ICR mice (Samtako, Korea) weighing $20-25 \mathrm{~g}$, in groups of 10-12, were used for behavioral experiments. Animals were housed in acrylic cages $(45 \times 60 \times 25 \mathrm{~cm})$ with water and food available ad libitum under an artificial 12-h light/dark cycle (light on at 7:00) and at a constant temperature $\left(22 \pm 2^{\circ} \mathrm{C}\right)$. Mice were housed in the departmental room for 1 week before testing to ensure adaptation to the new environment. All of the behavior experiments were performed between 10:00 and 17:00 $\mathrm{pm}$. All the animals were maintained in accordance with the National Institute of Toxicological Research on the Korea Food and Drug Administration guidelines for the care and use of laboratory animals.

\section{Experimental compounds and drugs}

ZSS was purchased from an oriental drug store in Seoul, Korea. ZSS $(300 \mathrm{~g})$ were extracted three times with 11 of hexane in a reflux condenser for $24 \mathrm{~h}$. The residues were extracted with methanol for $24 \mathrm{~h}$, and this methanol extraction was evaporated to dryness by rotary evaporation; the solvent was removed by rotary evaporation and partitioned between $5 \%$ hydrochloric acid $(60 \mathrm{ml})$ and ether $(50 \mathrm{ml})$. This aqueous acid solution was extracted three times more with ammonia hydrate $(\mathrm{pH}$ 9.0) and chloroform $(60 \mathrm{ml} \times 3)$. The alkaloid fractions in chloroform solution were combined, filtered through Whatman No.1 filter paper, and concentrated using a rotary vacuum evaporator followed by lyophilization. The yield of CFAZ was about $0.03 \%$ (w/w) (Park et al., 2004).

\section{Elevated plus-maze test}

The elevated plus-maze apparatus consists of four arms $(30 \times 5 \mathrm{~cm})$ elevated $45 \mathrm{~cm}$ above the floor, with each arm positioned at $90^{\circ}$ relative to the adjacent arms. The two enclosed arms had $30 \mathrm{~cm}$ walls and to facilitate grip on the open arms these included a raised edge of $0.25 \mathrm{~cm}$. Open and closed arms were connected via a 
central area $(5 \times 5 \mathrm{~cm})$ to form a plus sign. The maze floor was constructed of black Plexiglas and the wall of the enclosed arms was constructed of clear Plexiglas (Chen et al., 2003). Four 25-W red fluorescent lights arranged as a cross at $100 \mathrm{~cm}$ above the maze were used as the source of illumination and the video camera was suspended above the maze record movements for analysis. Mice were randomly assigned (with a slight adjustment for matched body-weight) to experimental groups. Test commenced by placing a mouse on the central platform of the maze facing an open arm. The number of entries into and the time spent on each of the two types of arms were recorded during the 5-min trial (Klodzinska et al., 2004; Yu et al., 2007). An arm entry was defined as all four paws having crossed the dividing line between an arm and the central area. The plus-maze was thoroughly cleaned with $70 \%$ methanol after each trial. Mice were randomly allocated to the following groups: control (saline with $1 \%$ CMC (p.o.), diazepam (2.0 mg/kg p.o.), and CFAZ (2.0, 4.0 and $8.0 \mathrm{mg} / \mathrm{kg}$, p.o.).

\section{Hole-board test}

The hole-board apparatus (Ugo Basile, Italy) consisted of gray Perspex panels $(40 \times 40 \mathrm{~cm}, 2.2 \mathrm{~cm}$ thick) with 16 equidistant holes each $3 \mathrm{~cm}$ in diameter spaces on the floor. Photocells below the surface of the hole measured the number of head-dips. The board was positioned 15 $\mathrm{cm}$ above a table. Mice were randomly allocated to the following groups: control (normal saline with 1\% CMC (p.o.), diazepam (0.5 mg/kg, p.o.), and CFAZ (2.0, 4.0 and $8.0 \mathrm{mg} / \mathrm{kg}$, p.o.). Each mouse was individually placed on the center of the board facing away from the observer and allowed to freely roam about the apparatus prior to the testing. Diazepam and CFAZ were administered 30 and $60 \mathrm{~min}$ before the test, respectively. The number of head dips on the hole-board was counted for $5 \mathrm{~min}$ (Takeda et al., 1998; Wei et al., 2007; Silva et al., 2007). After each trial, the floor of the apparatus was wiped absolute methanol to remove traces of previous paths. This test session also was recorded with a camera mounted vertically above the hole-board test.

\section{Open field test}

Open field test was performed using the ambulatory monitor apparatus (ENV-520 SN 10317). The open field area was made of acrylic, it consisted 4 transparent walls and a white floor $(30 \times 30 \times 15 \mathrm{~cm})$. The open field was divided into 5 parts, 4 corner zones and a central zone. CFAZ (2.0, 4.0 and $8.0 \mathrm{mg} / \mathrm{kg}$, p.o.) was treated to the animals $1 \mathrm{~h}$ before the test and diazepam was adminis- trated to mice 30 min prior to the behavior experiment. Mice was put in the center of the open field box and tested for $1 \mathrm{~h}$. The ambulatory time spent in the central zone was recorded. After each individual mice session the plate should cleaned using $70 \%$ methanol to remove the traces of the animals.

\section{Locomotor activity}

Since the plus-maze experiment was affected by changes in locomotor activity, an additional experiment was carried out with the specific aim of monitoring the activity. Separately from the experiment above, spontaneous locomotor activity was measured automatically with a tilting-type ambulometer (AMB-10, O'Hara, Japan). Each mouse was placed in the activity cage $(20 \mathrm{~cm}$ in diameter, $18 \mathrm{~cm}$ in height) and after an adaptation period of 10 $\mathrm{min}$, the test compound administration protocol was implemented (Park et al., 2005). Diazepam (2 mg/kg, p.o.) and CFAZ (2.0, 4.0 and $8.0 \mathrm{mg} / \mathrm{kg}$, p.o.) were administered to the animals $30 \mathrm{~min}$ and $60 \mathrm{~min}$ prior to the experiment respectively and ambulatory activity was measured for 1 hour after the administration of the agents.

\section{Grip strength meter}

Accordingly, the first 5 sessions of training were limited to handing each animal for $5 \mathrm{~min}$. then, there were 10 training sessions during which animals were held around the midsection, facing the handle of the grip strength meter (GSM, designed by TSE-Systems and distributed by Scipro, Inc.), and one forearm was manually restrained by the experiment. When the unrestrained forepaw is brought into contact with the handle, the animals reliably grasp the bar, and the animal is then gently pulled away form the device (Kehl et al., 2000). The GSM then measure the maximal force before the animal releases the bar. Each testing session was performed for both forepaws three times $60 \mathrm{~min}$ and $30 \mathrm{~min}$ after the administration of CFAZ (2.0, 4.0 and $8.0 \mathrm{mg} / \mathrm{kg}$, p.o.) and diazepam ( $2 \mathrm{mg} / \mathrm{kg}$, p.o.) respectively.

\section{Cell culture}

Primary cultured cerebellar neurons enriched in granule cells were prepared from cerebella of 8-day-old Sprague-Dawley rats as previously described (Houston et al., 2006). Briefly, cells were plated $\left(1 \times 10^{6}\right.$ cells per $\left.0.2 \mathrm{ml}\right)$ in 96 microplates or $\left(2 \times 10^{6}\right.$ cells per $\left.2.0 \mathrm{ml}\right)$ in $60-\mathrm{mm}$ dishes pre-coated with poly-D-lysine $(10 \mu \mathrm{g} / \mathrm{ml})$ (Sigma, St. Louis, MO, USA) and were cultured in basal Eagle's medium (Life Technologies, Gaithersburg, MD, USA) 
supplemented with $10 \%$ heat-inactivated fetal bovine serum (Life Technologies), $2 \mathrm{mM}$ glutamine, gentamicin (100 $\mu \mathrm{g} / \mathrm{ml}$, antibiotic-antimycotic solution (10 $\mathrm{ml} / \mathrm{l})$ (Sigma) and $25 \mathrm{mM} \mathrm{KCl}$; such a high concentration of potassium was necessary to induce persistent depolarization, which promotes the survival of granule cells. The cells were incubated for 6 to 9 days in a humidified $5 \%$ $\mathrm{CO}_{2} / 95 \%$ air atmosphere at $37^{\circ} \mathrm{C}$. Cytosine arabinofuranoside (final concentration, $10 \mu \mathrm{M}$ ) (Sigma) was added to cultures 18-24 $\mathrm{h}$ after plating to inhibit the proliferation of non-neuronal cells. After 7 days, the cultured cells were used for the measurements.

\section{Measurement of intracellular chloride influx}

The intracellular $\mathrm{Cl}^{-}$concentration in cultured cerebellar granule cells was estimated using the $\mathrm{Cl}^{-}$sensitive fluorescence probe MQAE according to the method of West and Molloy with a slight modification (West et al., 1996). The buffer $(\mathrm{pH}$ 7.4) used contained the following: $2.4 \mathrm{mM}$ $\mathrm{HPO}_{4}^{2-}, 0.6 \mathrm{mM} \mathrm{H}_{2} \mathrm{PO}_{4}^{-}, 10 \mathrm{mM}$ HEPES, $10 \mathrm{mM}$ D-glucose and $1 \mathrm{mM} \mathrm{MgSO}_{4}$. A variety of MQAE-loading conditions were assessed. The cells were incubated overnight in a medium containing $10 \mathrm{mM}$ MQAE (Dojindo, Japan). After loading, the cells were washed three times in the relevant $\mathrm{Cl}^{-}$containing buffer. The buffer was replaced with buffer with or without the compounds or control. Repetitive fluorescence measurements were initiated immediately using a FLUOstar (excitation wavelength: $320 \mathrm{~nm}$; emission wavelength: $460 \mathrm{~nm}$; BMG Lab Technology, Germany). The data is presented as the relative fluorescence Fo/F, where $\mathrm{Fo}$ is the fluorescence without $\mathrm{Cl}^{-}$ions and $F$ is the fluorescence as a function of time. The Fo/F values were directly proportional to $[\mathrm{Cl}]$.

\section{$\mathrm{GABA}_{A}$ receptors subunits expression}

Primary cultured cells were treated with CFAZ or diazepam after 8 days cultured. CFAZ was dissolved in ethanol and diluted sequentially in culture medium to final concentrations of $8.0 \mu \mathrm{g} / \mathrm{ml}$. Diazepam was diluted in the medium to $10 \mu \mathrm{M}$ and then treated to the cells. For the control group, cells were treated with only culture medium without CFAZ. The culture was completely replaces every day. After treatment of CFAZ and diazepam for 5 days, cells were harvested and treated with lysis buffer. The extract were centrifuged at 20,000 $\times \mathrm{g}$ for $20 \mathrm{~min}$. Equal amount of proteins were separated on a SDS/12\% polyacrylamide gel, and transferred to a nitrocellulose membrane (Hyboud ECL, Amersham Pharmacia Biotech Inc., Piscataway, NJ, USA). The blots were blocked overnight at $4^{\circ} \mathrm{C}$ with $5 \%(\mathrm{w} / \mathrm{v})$ non-fat dried milk in a Tris-buffered saline solution (10 mM Tris $\mathrm{pH} 8.0$ and $150 \mathrm{mM} \mathrm{NaCl}$ ) containing $0.05 \%$ Tween-20 (TBST). The membrane was incubated with the specific antibodies, rabbit polyclonal antibodies against $\mathrm{GABA}_{\mathrm{A}}$ receptors subunit (1:500) (Santa Cruz Biotechnology Inc.) or GAD65/67, for $4 \mathrm{~h}$ at room temperature. The blot was washed in TBST for 3 times and then incubated for $2 \mathrm{~h}$ with the corresponding conjugated anti-rabbit immunoglobulin G-horseradish peroxidase (1:2000) (Santa Cruz Biotechnology Inc.). The membrane was washed in TBST for 3 times and the immunoreactive proteins were detected using the ECL western blotting detection system.

\section{Statistical analysis}

The results are presented as the mean \pm S.E.M. and the significance of the effects of the compounds was assessed using analysis of variance (ANOVA). In case of significant variation, the individual values were compared with Dunnett's test.

\section{RESULTS}

\section{Anxiolytic-like effects of CFAZ on the elevated plus- maze test}

As the positive control, diazepam (2 $\mathrm{mg} / \mathrm{kg})$ increased open arm entries $(P<0.001)$ and time spent on open arms $(P<0.01)$ significantly compared with the vehicle group $(P<0.01)$. The mice treated with CFAZ $(8.0 \mathrm{mg} / \mathrm{kg})$ also increased the percentage of open arm entries $(P<0.05)$ and time spent on open arms $(P<0.05)$ compared with that of the saline animals (Fig. 1).

\section{Anxiolytic-like effects of CFAZ on the hole-board test}

In order to investigate the exploratory and anxiolytic effect, the hole-board test was tested to the animals that treated with diazepam and CFAZ. Both of the diazepam $(0.5 \mathrm{mg} / \mathrm{kg}, P<0.05)$ and CFAZ (8.0 mg/kg, $P<0.05)$ significantly increased the head dips (Fig. 2).

\section{Anxiolytic-like effects of CFAZ on the open field test}

Open field test was performed in mice for $1 \mathrm{~h}$ after the administration of CFAZ or 30 min after the treatment of diazepam. It showed that CFAZ (2.0, 4.0 and $8.0 \mathrm{mg} / \mathrm{kg}$, $\mathrm{P}<0.001)$ and diazepam $(0.5 \mathrm{mg} / \mathrm{kg}, \mathrm{P}<0.001)$ increased the percentages of central zone ambulatory time significantly compared with that of control group (Fig. 3).

\section{Effects of CFAZ on the locomotor activity}

The locomotor activity of mice treated with different dos- 

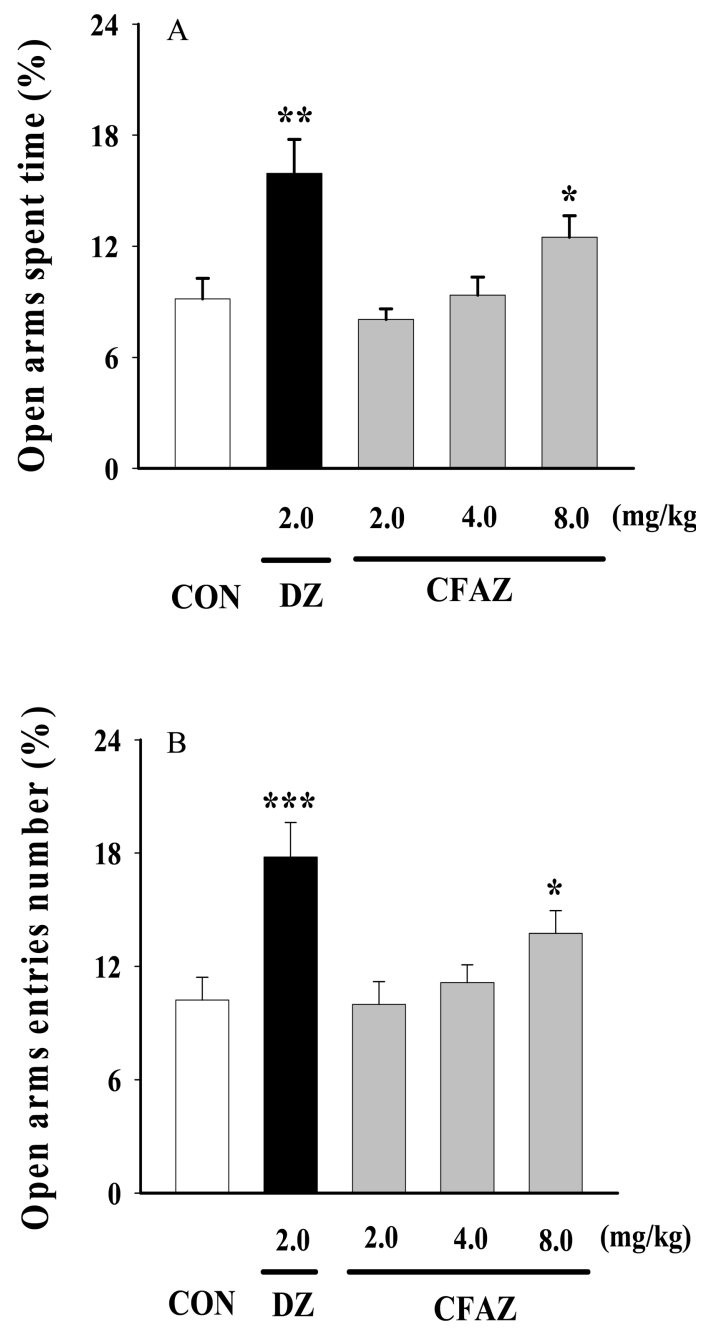

Fig. 1. Effects of CFAZ on the percentage of open arm entries and time spent in open arms on the elevated plus-maze in mice. Open arm entries and spent time in open arms by elevated plus-maze were measured for $5 \mathrm{~min}, 30 \mathrm{~min}$ after oral administration of diazepam and $1 \mathrm{~h}$ after the administration of CFAZ. Data are expressed as mean \pm S.E.M. ${ }^{*} P<0.05$, ${ }^{* *} p<$ $0.01,{ }^{\star \star \star} P<0.001$, compared with that of vehicle-treated control.

ages of CFAZ or diazepam was compared with that of mice treated with vehicle. Locomotor activity was significantly decreased by diazepam $(2.0 \mathrm{mg} / \mathrm{kg}, P<0.001)$. However; CFAZ at the doses of 2.0, 4.0 and $8.0 \mathrm{mg} / \mathrm{kg}$ did not affect locomotor activity in tested animals (Fig. 4).

\section{Effects of CFAZ on grip strength meter}

In the grip strength meter test, diazepam $(2.0 \mathrm{mg} / \mathrm{kg}$, $P<0.001)$ significantly decreased the grip force compared with the control group. But, CFAZ has no effect in decreasing the grip force at the doses of 2.0, 4.0 and 8.0 $\mathrm{mg} / \mathrm{kg}$ (Fig. 5).

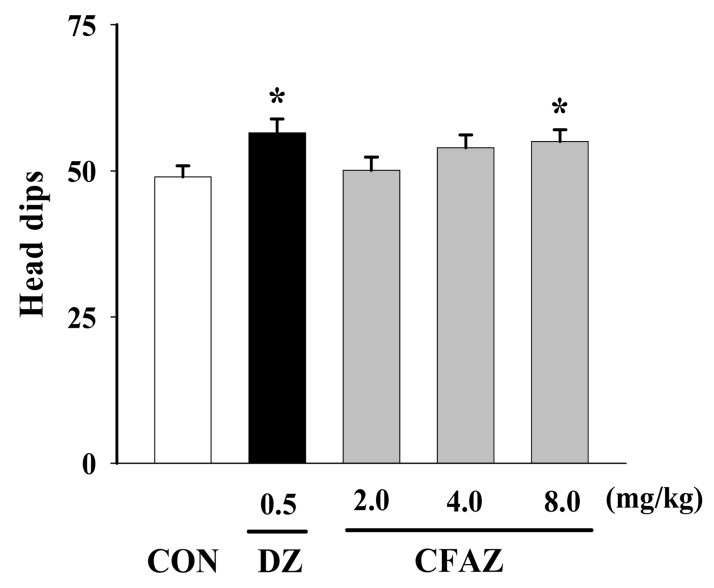

Fig. 2. Effects of CFAZ on head-dips in hole-board test in mice. Head-dips by hole-board test were measured for $5 \mathrm{~min}$, $30 \mathrm{~min}$ after oral administration of diazepam and $1 \mathrm{~h}$ after CFAZ treatment. Data are expressed as mean \pm S.E.M. ${ }^{*} P<$ 0.05 , compared with that of control group, respectively.

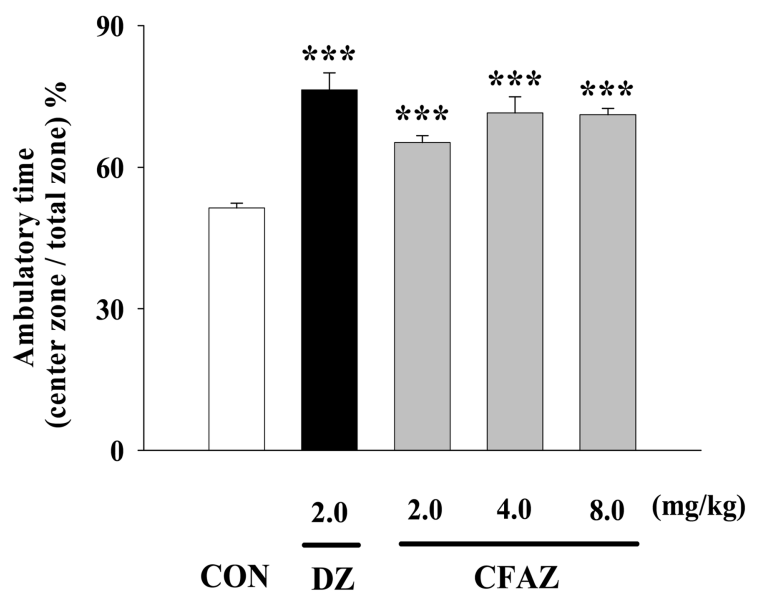

Fig. 3. Effects of CFAZ in open field test in mice. Open field test was measured for $1 \mathrm{~h}, 30 \mathrm{~min}$ after oral administration of diazepam and $1 \mathrm{~h}$ after CFAZ treatment. Data are expressed as mean \pm S.E.M. ${ }^{* \star \star} P<0.001$, compared with that of control group.

\section{Effects of CFAZ on intracellular chloride influx}

Resting inreacellular $\mathrm{Cl}^{-}$concentrations were calibrated using standard $\mathrm{Cl}^{-}$solutions of $0,15,30,45,60$ and 75 $\mathrm{mM} \mathrm{Cl}$. Appropriate amounts of methylsulfate were used to replace $\mathrm{Cl}^{-}$in these solutions. Tributyltin chloride (5.0 $\mu \mathrm{M})$ and nigericin $(5.0 \mu \mathrm{M})$ were present to artificially facilitate the balance between intracellular $\mathrm{Cl}^{-}$and extracellular $\mathrm{Cl}^{-}$concentrations. Resting $\left[\mathrm{Cl}^{-}\right] i$ in cultured cerebella granule cells was $10.28 \mathrm{mM}$, and treatment of granule cells with CFAZ 4,8 and $16 \mu \mathrm{g} / \mathrm{ml}$ increased chloride influx to $20.20,21.59$ and $23.43 \mathrm{mM}(\mathrm{P}<0.01, \mathrm{P}<0.01$, 
Huishan Han et al.

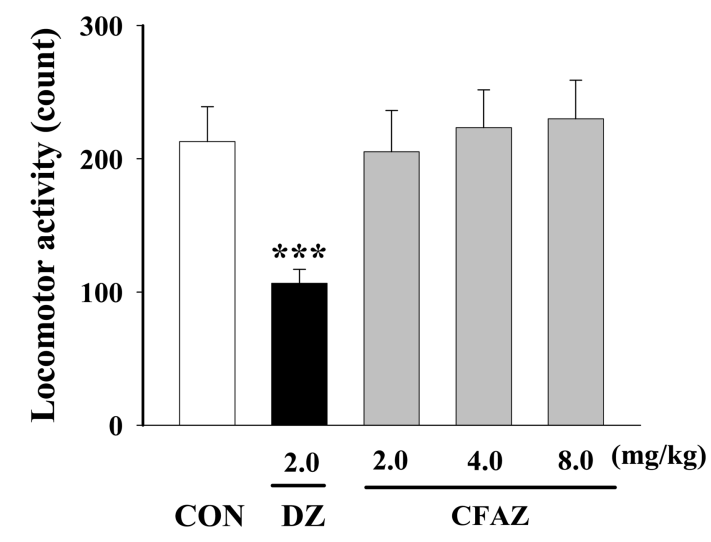

Fig. 4. Effects of CFAZ on locomotor activity test in mice. Ambulation activity was measured for $1 \mathrm{~h}, 30$ min after oral administration of diazepam and $1 \mathrm{~h}$ after the administration of CFAZ. Data are expressed as mean \pm S.E.M. ${ }^{\star \star \star} P<0.001$, compared with that of control group, respectively.

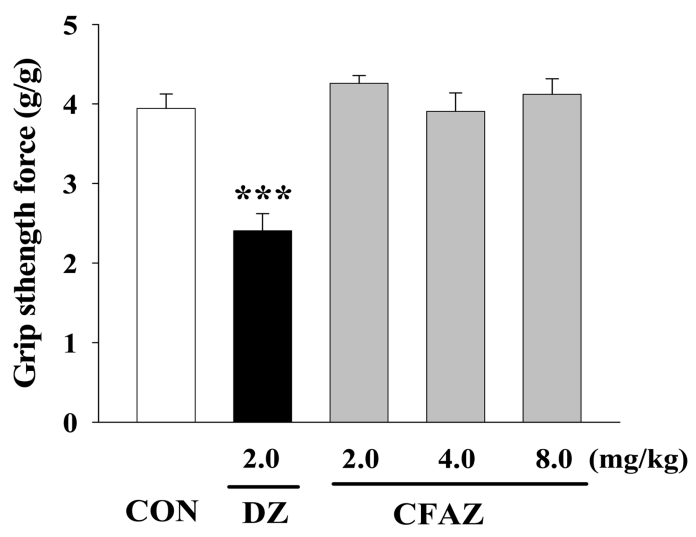

Fig. 5. Effects of CFAZ on grip strength meter test in mice. Mice were tested $30 \mathrm{~min}$ after oral administration of diazepam and $1 \mathrm{~h}$ after CFAZ. Data are expressed as mean \pm S.E.M. ${ }^{\star \star \star} P<0.001$, compared with that of vehicle group, respectively.

$\mathrm{P}<0.001)$. Also, diazepam $10.0 \mu \mathrm{M}$ increased the chloride influx to $15.12 \mathrm{mM}(\mathrm{P}<0.05)$, compared with the control group (Fig. 6).

\section{Expression of GABA ${ }_{A}$ receptors subunits by CFAZ}

$\mathrm{GABA}_{A}$ receptors subunits expression was examined after treatment with CFAZ $8.0 \mu \mathrm{g} / \mathrm{ml}$ and diazepam 10.0 $\mu \mathrm{M}$ in the cerebellar granule cells for 5 days. Diazepam increased the $\alpha$-and $\gamma$-subunits expressions $(P<0.05$, $\mathrm{P}<0.05)$ but had no effect on the abundance of $\beta$-subunit expression. At the same time, CFAZ increased $\gamma$-subunit expression $(P<0.05)$, but had no effects in changing the expression of the $\alpha$-and $\beta$-subunits of $\mathrm{GABA}_{\mathrm{A}}$ receptors (Fig. 7).

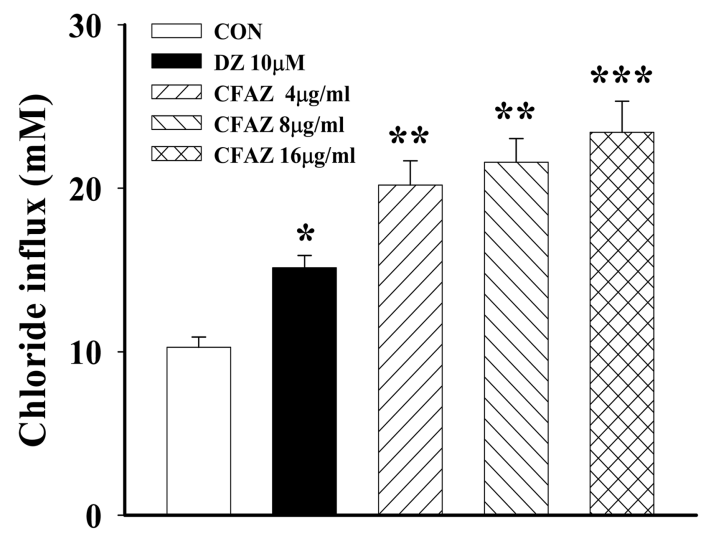

Fig. 6. Effects of CFAZ on chloride influx in primary cultured cerebellar granule cells. After the culture of cerebellar neuron cells for 5 days, the cells were incubated with MQAE overnight, and then CFAZ $(8 \mu \mathrm{g} / \mathrm{ml})$ and diazepam $(10 \mu \mathrm{M})$ were treated to cells. Repetitive fluorescence measurements were inhibited immediately using a FLUO star. Each column represents the mean \pm S.E.M. ${ }^{\star} P<0.05,{ }^{\star \star} P<0.01,{ }^{\star \star *} p<0.001$, compared with that of control group.

\section{DISCUSSION}

Major depression and anxiety are the most prevalent psychiatric disorders among the world population (Rouillon, 1999). Anxiety and depression often occur as co-morbid illnesses, share many common symptoms, adversely affecting clinical and treatment outcomes. The treatment of anxiety or depression still not trivial (Rex et al., 2002). There has been considerable interest in studying co-morbidity of anxiety and depression.

In this study, the effects of CFAZ, the major alkaloid fraction extracted from ZSS were performed in animal models of anxiety, such as elevated plus-maze, hole-board test, open field teat, locomotor activity and grip strength meter, which are classical models for screening central nervous system actions providing in formation about anxiety, myo-relaxant activity and depression (Silva et al., 2007; de Melo et al., 2006).

One of the most widely used animal models for screening putative anxiolytics is the elevated plus-maze (Klodzinska et al., 2004; Wei et al., 2007), in which rodents show an avoidance of exposed open areas of the maze, which are presumed to be the most aversive, and a preference for sections enclosed by protective walls (Weiss et al., 1998). The anxiolytic effectiveness of a drug is illustrated by a significant statistical augmentation of parameters in open arms. Conventional anxiety indices in the elevated plus-maze test comprise percent open arm entries and percent time spent in these areas 
(A)

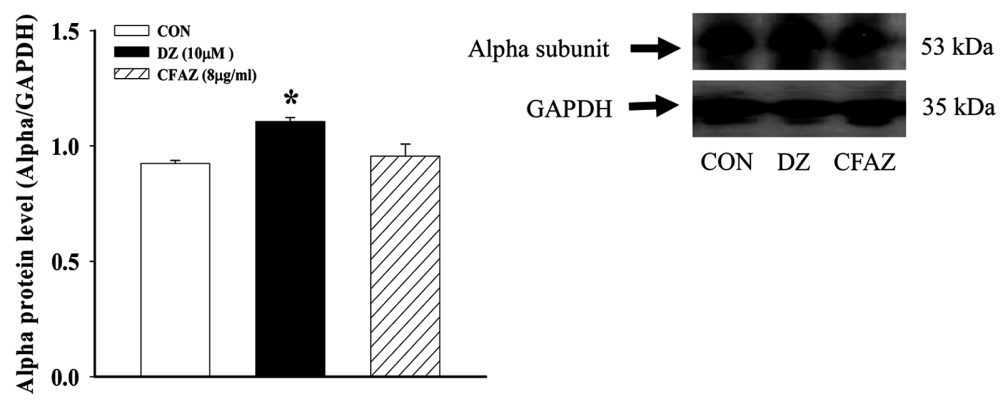

(B)

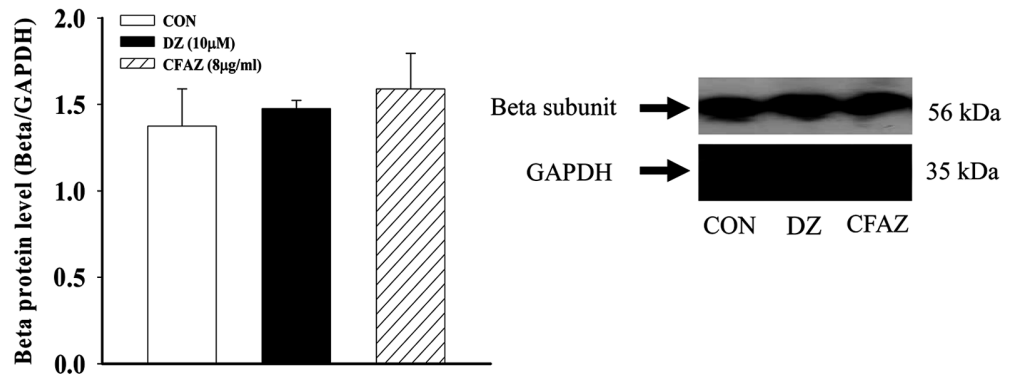

(C)

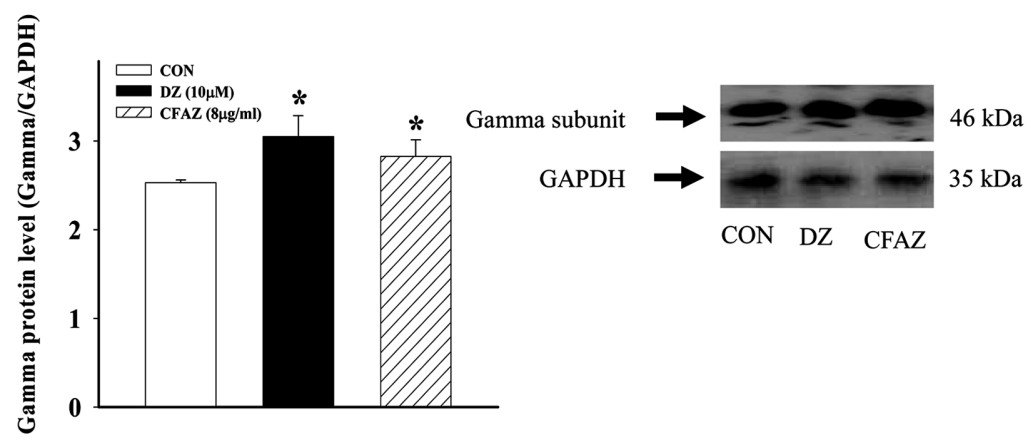

Fig. 7. Effects of CFAZ on $\mathrm{GABA}_{A}$ receptors subunits expression. After the culture of cerebellar neuron cells for 7 days, CFAZ (8 $\mu \mathrm{g} / \mathrm{ml}$ ) or diazepam $(10 \mu \mathrm{M})$ were treated to the cells for 5 days. Then $\mathrm{GABA}_{A}$ receptor subunits expression was measured using western blot. Each column represents the mean \pm S.E.M. ${ }^{*} p<0.05$, compared with that of control group.

in the maze, with anxiolytics generally increasing and anxiogenics decreasing these measures. In the present study, CFAZ (8.0 mg/kg, p.o.) increased the percentages of entries into open arms and time spent in open arms which indicated the anxiolytic-like effect.

The hole-board test provides a simple method for measuring the response of an animal to an unfamiliar environment and is widely used to assess emotionality, anxiety and /or responses to stress in animals (Nolan et al., 1973). Head-dipping behavior was sensitive to changes in the emotional state of the animal, and suggested that the expression of an anxiolytic state in animals may be reflected by an increase in head-dipping behavior (Takeda et al., 1998). In our study, CFAZ (8.0 $\mathrm{mg} / \mathrm{kg}$ ) increased the head dips in the hole-board test which also showed the anxiolytic-like effects.

Open field test was used to evaluate the exploratory activity of the animal. This was demonstrated through more central zone visitations by CFAZ during the $1 \mathrm{~h}$ test. From the result of open field test, we found that the percentage of ambulatory time in central zone was increased by the treatment of CFAZ or diazepam which indicated the exploratory effect of CFAZ.

Diazepam has been used as a standard anxiolytic and also has been frequently employed in behavioral pharmacology as a reference compound of potentially 
anxiolytic-acting substances. But at the same time, most benzodiazepines, typical GABA/benzodiazepine receptor agonist such as diazepam have the side-effect such as the muscle relaxation and depression mood. Differ from diazepam, CFAZ showed anxiolytic-like effects without affecting locomotor activity at lower doses (2.0, 4.0 and $8.0 \mathrm{mg} / \mathrm{kg}$ ), indicating that the extract exerts anxiolytic-like and hypnotic effects at different doses. In the grip strength meter test, CFAZ also had no effect in decreasing the strength force which showed that CFAZ has no effect in muscle relaxation. Therefore, it suggested that CFAZ showed better profile than diazepam.

It is well known that benzodiazepines facilitate the ability of GABA to activate the GABA receptors intrinsic $\mathrm{Cl}^{-}$channel and in turn facilitate inhibitory neurotransmission. This is manifest as an increase in the frequency of the ion channel opening in response to GABA. CFAZ increased the chloride influx significantly when treated the cerebella granule cells, compared with that of control group. It is generally accepted that GABA-receptors agonists decrease anxiety by facilitating the neuronal influx of chloride. Therefore, it showed that anxiolytic-like effects of CFAZ might be mediated by GABA-benzodiazepine receptors-activated $\mathrm{Cl}^{-}$channel opening.

$\mathrm{GABA}_{\mathrm{A}}$ receptors are heteromeric ligand-gated chloride ion channels that are activated by brief releases of GABA into the synaptic cleft. GABA released from presynaptic inter-neuronal terminals binds to postsynaptic GABA receptors that gate a chloride ion flux into the postsynaptic cell membrane. This ionic flux typically hyperpolarizes the post-synaptic neuronal membrane, making it less likely that arrival of excitatory neurotransmitters will be able to depolarize the post-synaptic cell sufficiently above the threshold for action potential initiation. The traditional hypnotics and anxiolytic drugs, such as barbiturates and benzodiazepines, enhance GABA transmission via the $\mathrm{GABA}_{A}$ receptor. The $\alpha$ and $\beta$ subunits provide the binding site for the GABA molecule while $\alpha$ and $\gamma$ subunits are sensitive to benzodiazepine binding (Whiting 1999; Bateson, 2004). We found that CFAZ increased the abundance of GABA $A_{A}$ receptor $\gamma$ subunit but had no effect in influencing the abundance the $\alpha$-subunit and $\beta$-subunit. It indicated that CFAZ increased GABA receptors to benzodiazepine by influence GABA receptors subunits compositions.

To summarize, all the data presented here indicate that CFAZ induced anxiolytic-like effects in the plusmaze test and hole-board test while has hypnotic or muscle-relaxant activity at low doses that do not influ- ence locomotor activity and grip force. These results suggest that CFAZ has anxiolytic-like effects, and these pharmacological effects may be mediated by GABAbenzodiazepine receptors-activated $\mathrm{Cl}^{-}$channel opening and exert its anxiolytic effect by increasing GABA receptors to benzodiazepines or GABA by influence GABA receptors subunits compositions. In conclusion, CFAZ might be a good condition for treating anxiety. Further investigation is needed for CFAZ derivatives with strong pharmacological actions and their possible mechanisms.

\section{ACKNOWLEDGEMENTS}

This work was supported by the Research Grant of the Chungbuk National University in 2007.

\section{REFERENCES}

Ahn, N. Y., Jung, J. W., Oh, H. R., Shin, J. S. and Hyeon, S. Y. (2004). Anxiolytic-like effects of Sanjoin-Tang extracts and its ingredients in the elevated plus-maze in mice. J. Appl. Pharmacol. 12, 151-156.

Adzu, B., Amos, S., Dzarma, S., Wambebe, C. and Gamaniel, K. (2002). Effect of Zizyphus spina-christi wild aqueous extract on the central nervous system in mice. J. Ethnopharmacol. 79, 13-6.

Bateson, A. N. (2004). The benzodiazepine site of the $\mathrm{GABA}_{A}$ receptor: an old target with new potential? Sleep Med. 5, 9-15.

Brailowsky, S. and Garcia, O. (1999). Ethanol, GABA and epilepsy. Arch. Med. Res. 30, 3-9.

Bonnert, T. P., McKernan, R. M., Farrar, S., le Bourdellès, B., Heavens, R. P., Smith, D. W., Hewson, L., Rigby, M. R., Sirinathsinghii, D. J., Brown, N., Wafford, K. A. and Whiting, P. J. (1999). theta, a novel gamma-aminobutyric acid type A receptor subunit. Proc. Natl. Acad. Sci. U S A. 96, 9891-9896.

Barnard, E. A., Skolnick, P., Olsen, R.W., Mohler, H., Sieghart, W., Biggio, G., Braestrup, C., Bateson, A. N. and Langer, S. Z. (1998). International Union of Pharmacology. XV. Subtypes of gamma-aminobutyric acidA receptors: classification on the basis of subunit structure and receptor function. Pharmacol. Rev. 50, 291-313.

Beck, A. T. (1988). Cognitive approaches to panic: theory and therapy. In Panic: Psychological Perspective (J. D. Mater and S. Rachman Ed.), pp. 91-109. Hillsdale: Lawrence Erlbaum Associates.

Chen, S. W., Xin, Q., Kong, W. X., Min, L. and Li, J. F. (2003). Anxiolytic-like effect of succinic acid in mice. Life Sci. $\mathbf{7 7 3}$, 3257-3264.

Chung, K. F. and Lee, C. K. (2002). Over-the-counter sleeping pills: a survey of use in Hong Kong and a review of their constituents. Gen. Hosp. Psychiatry. 24, 430-435.

Cheng, G. Bai, Y. J., Zhao, Y. Y., Yao, J., Liu, Y., Tu, G. Z., Ma, L. B., Liao, N. and Xu, X. Y. (2000). Flavonoids from Zizyphus jujube Mill var. Spinosa. Tetrahedron. 56, 8915-8920. 
Duarte, F. S., Duzzioni, M., Mendes, B. G. Pizzolatti, M. G., De Lima, T. C. (2007). Participation of dihydrostyryl-2-pyrones and styryl-2-pyrones in the central effects of Polygala sabulosa (Polygalaceae), a folk medicine topical anesthetic. Pharmacol. Biochem. Behav. 86, 150-161.

de Melo, C. T., Monteiro, A. P., Leite, C. P., de Araújo, F. L., Lima, V. T., Barbosa-Filho, J. M., de França Fonteles, M. M., de Vasconcelos, S. M., de Barros Viana, G. S. and de Sousa, F. C. (2006). Anxiolytic-like effects of (O-methyl)-N2,6-dihydroxybenzoyl-tyramine (riparin III) from Aniba riparia (Nees) Mez (Lauraceae) in mice. Biol. Pharm. Bull. 29, 451454

Eisenberg, D. M., Davis, R. B., Ettner, S. L., Appel, S., Wilkey, S., Van Rompay, M. and Kessler, R. C. (1998). Trends in Alternative Medicine Use in the Unites States, 1990-1997: Results of A Follow-up National Survey. Complement Ther. Med. 7, 1569-1575.

Gardner, C. R., Tully, W. R. and Hedgecock, C. J. (1993). The rapidly expanding range of neuronal benzodiazepine receptor ligands. Prog. Neurobiol. 40, 1-61.

Han, H. S., Ma, Y., Eun, J. S., Hong, J. T. and Oh, K. W. (2007) Anxiolytic-like Effects of Methanol Extract of Zizyphi Spinosi Semen in Mice. J. Appl. Pharmacol. 15, 175-181.

Houston, C. M. and Smart, T. G. (2006). CaMK-II modulation of GABA(A) receptors expressed in HEK293, NG108-15 and rat cerebellar granule neurons. Eur. J. Neurosci. 24, 2504-2514.

Hui, K. M., Huen, M. S., Wang, H. Y., Zheng, H., Sigel, E., Baur, R., Ren, H., Li, Z. W., Wong, J. T. and Xue, H. (2002). Anxiolytic effect of wogonin, a benzodiazepine receptor ligand isolated from Scutellaria baicalensis Georgi. Biochem. Pharmacol. 64, 1415-1424.

Klodzinska, A., Tatarczyñska, E., Chojnacka-Wójcik, E., Nowak, G. Cosford, N. D. and Pilc, A. (2004) Anxiolytic-like effects of MTEP, a potent and selective mGlu5 receptor agonist does not involve GABA(A) signaling. Neuropharmacol. 47, 342-350.

Korpi, E. R., Mihalek, R. M., Sinkkonen, S. T., Hauer, B., Hevers, W., Homanics, G. E., Sieghart, W. and Lüddens, H. (2002). Altered receptor subtypes in the forebrain of GABA(A) receptor delta subunit-deficient mice: recruitment of gamma 2 subunits. Neurosci. 109, 733-743.

Kehl, L. J., Trempe, T. M. and Hargreaves, K. M. (2000). A new animal model for assessing mechanisms and management of muscle hyperalgesia. Pain 85, 333-343.

Kaupmann, K., Huggel, K., Heid, J., Flor, P. J., Bischoff, S., Mickel, S. J., McMaster, G., Angst, C., Bittiger, H., Froestl, W. and Bettler, B. (1997). Expression cloning of GABA(B) receptors uncovers similarity to metabotropic glutamate receptors. Nature. 386, 239-246.

Lee, S. S., Lin, B. F. and Liu, K. C. (1996). Three triterpence esters from Zizyphus Jujuba. Phytochem. 43, 847-851.

Ma, Y., Han, H. S., Nam, S. Y., Kim, Y. B. Hong, J. T., Yun, Y. P., Oh, K. W. (2008). Cyclopeptide alkaloid fraction from Zizyphi Spinosi Semen enhances pentobarbital-induced sleeping behavoirs. J. Ethanopharmacol., 117, 318-324.

Nolan, N. A. and Parkes, M. W. (1973). The effects of benzodiazepines on the behavior of mice on a hole-board. Psychop- harmacol. 29, 277-286.

Park, J. H., Cha, H. Y., Seo, J. J., Hong, J. T., Han, K. and Oh, K. W. (2005). Anxiolytic-like effects of ginseng in the elevated plus-maze model: comparison of red ginseng and sun ginseng. Prog. Neuropsychopharmacol. Biol. Psychiatry. 29, 895-900.

Park, J. H., Lee, H. J., Koh, S. B., Ban, J. Y., Seong, Y. H. (2004). Protection of NMDA-induced neuronal cell damage by methanol extract of Zizyphi Spinosi Semen in cultured rat cerebellar granule cells. J Ethnopharmacol. 95, 39-45.

Peng, Z. C. and Zhu, J. J. (2001). Research advances in chemical constituents and pharmacological effects of Semen Zizyphi Spinosae. Lishizhen Med. Medica Res. 12, 86-87.

Peng, W. H., Hsieh, M. T., Lee, Y. S., Lin, Y. C., Liao, J. (2000). Anxiolytic effect of seed of Ziziphus jujuba in mouse models of anxiety. J Ethnopharmacol. 72, 435-441.

Rex, A., Morgenstern, E. and Fink, H. (2002). Anxiolytic-like effects of kava-kava in the elevated plus maze test--a comparison with diazepam. Prog. Neuropsychopharmacol. Biol. Psychiatry. 26, 855-860.

Rouillon, F. (1999). Anxiety with depression: a treatment need. Eur. Neuropsychopharmacol. 3, 87-92.

Silva, M. I., de Aquino Neto, M. R., Teixeira Neto, P. F., Moura, B. A., do Amaral, J. F., de Sousa, D. P., Vasconcelos, S. M. and de Sousa, F. C. (2007). Central nervous system activity of acute administration of isopulegol in mice. Pharmacol. Biochem. Behav. 88, 141-147.

Takeda, H., Tsuji, M. and Matsumiya, T. (1998). Changes in head-dipping behavior in the hole-board test reflect the anxiogenic and/or anxiolytic state in mice. Eur. J. Pharmacol. 350, 21-29.

Une, H. D., Sarveiya, V. P., Pal, S. C., Kasture, V. S. and Kasture, S. B. (2001). Nootropic and anxiolytic activity of saponins of Albizzia lebbeck leaves. Pharmacol. Biochem. Behav. 69, 439-444.

Whiting, P. J. (1999). The GABA-A receptor gene family: new targets for therapeutic intervention. Neurochem. Int. 34, 387-390.

Weiss, S. M., Wadsworth, G., Fletcher, A. and Dourish, C. T. (1998). Utility of ethological analysis to overcome locomotor confounds in elevated maze models of anxiety. Neurosci. Biobehav. Rev. 23, 265-271.

West, M. R. and Molloy, C. R. (1996). A microplate assay measuring chloride ion channel activity. Anal. Biochem. 241, 51-58.

Wei, X. Y., Yang, J. Y., Wang, J. H. and Wu, C. F. (2007). Anxiolytic effect of saponins from Panax quinquefolium in mice. $J$ Ethnopharmacol. 111, 613-618.

Yu, H. S., Lee, S. Y. and Jang, C. G. (2007). Involvement of 5HT1A and GABAA receptors in the anxiolytic-like effects of Cinnamomum cassia in mice. Pharmacol. Biochem. Behav. 87, 164-170.

Yuzurihara, M., Ikarashi, Y., Ishihara, K., Kushida, H., Ishige, A., Sasaki, H. and Maruyama, Y. (2000). Effects of subacutely administered saiboku-to, an oriental herbal medicine, on pharmacodynamics and pharmacokinetics of diazepam in rodents. Eur J Drug Metab. Pharmacokinet. 25, 127-136. 